\title{
UJI AKTIVITAS ANTIOKSIDAN EKSTRAK ETANOL DAUN SIRSAK (Annona muricata L) PADA TIKUS PUTIH (Rattus norvegicus) DIABETES MELITUS YANG DIINDUKSI ALOKSAN DENGAN PARAMETER MALONDIALDEHID (MDA)
}

\author{
Safriani Rahman, Rachmat Kosman, Inda Rahmaniar \\ Fakultas Farmasi Universitas Muslim Indonesia \\ Email : safriani rahman@yahoo.com.
}

\begin{abstract}
Hyperglycemia in Diabetes can caused the excessive production of Reactive Oxygen Species (ROS) in the body that will causes oxidative stress that tissue damage. Oxidative stress can indicated by increasing MDA levels. This research aims to know and determine the concentration ethanol extract of soursop leaves that have antioxidant activity to MDA levels in diabetic rats. 9 white rats were divided into 3 groups. All rats were induced by alloxan $110 \mathrm{mg} / \mathrm{Kg}$.BB intraperitoneally. Group I was administered with Na.CMC as a negative control, group II and III were administered with ethanol extract of soursop leaves 2,5\% and 5\%. Administration were given orally for 12 days orally. Examination of blood glucose and MDA levels conducted before and after the administration. MDA Assay performed with TBA method was based on reaction of MDA-TBA as measured on a spectrophotometer $532 \mathrm{~nm}$ wavelength. The results were analysized statistically by using randomized block design (RBD) method. Based on the research has been done, it was showed that the ethanol extract of soursop leaves can lower blood glucose levels of diabetic rats and extract with concentration of $5 \%$ has potential as an antioxidant activity that can reduce MDA levels in diabetic rat.
\end{abstract}

Key Words : Diabetes, Antioxidant, Malondialdhyde(MDA), Soursop Leaves

\section{PENDAHULUAN}

Diabetes melitus merupakan sekumpulan gejala pada seseorang yang ditandai dengan kadar glukosa darah yang melebihi nilai normal (hiperglikemia) yaitu $\geq 126 \mathrm{mg} / \mathrm{dL}$ ( kadar glukosa darah puasa ) atau $\geq$ 200 mg/dL ( kadar glukosa darah setelah minum larutan glukosa 75 gram) akibat tubuh kekurangan insulin baik absolut maupun relatif (Siswanto, 2012).
Hiperglikemia pada diabetes melitus ini dapat menyebabkan produksi Reactive Oxygen Species (ROS) atau radikal bebas yang berlebihan. Hiperglikemia akan menyebabkan terjadinya auto-oksidasi glukosa sehingga terbentuk radikal bebas, glikosilasi auto-oksidatif, dan meningkatnya jalur poliol yang akan menurunkan kemampuan antioksidan untuk meredam aktivitas radikal bebas dalam tubuh. Hal ini akan 
Uji Aktivitas Antioksidan Ekstrak Etanol Daun Sirsak Pada Tikus Putih Diabetes Melitus Yang Diinduksi Aloksan Dengan Parameter Malondialdehid

mempercepat pembentukan Reactive Oxygen Species ( ROS) (Wiyono , 2003).

Reactive Oxygen Species (ROS) yang berlebihan ini akan bereaksi dengan komponenkomponen sel dan menimbulkan stress oksidatif yang menyebabkan kerusakan jaringan pada manusia.Stress oksidatif dapat ditunjukkan dengan meningkatnya MDA serum. Salah satu tanaman tradisional yang berkhasiat sebagai antidiabetes dan antioksidan adalah daun sirsak. Berdasarkan penelitian sebelumnya, membuktikan bahwa fraksi air ekstrak etanol daun sirsakdosis $400 \mathrm{mg} / \mathrm{Kg}$ BB memiliki efek penurunan kadar glukosa tertinggi diantara fraksi n-heksan dan etil asetatdengan \% penurunan kadar glukosa sebesar $66,45 \%$ tikus putih diabetes yang diinduksi aloksan ( Adiyati I, 2011). Hasil pengujian aktivitas antioksidan dengan metode penangkapan radikal bebas DPPH menunjukkan bahwa ekstrak etanol daun sirsak memiliki $I_{50}$ sebesar 60,74 (Rianes R, 2012).

Berdasarkan hal tersebut di atas, maka perlu dilakukan penelitian mengenai aktivitas antioksidan dari daun sirsak ( Annona muricata L) terhadap kadar MDA darah tikus
putih(Rattus norvegicus) diabetes melitus yang diinduksi aloksan.

\section{METODE PENELITIAN}

\section{Alat dan Bahan Yang Digunakan}

Alat yang digunakan pada penelitian ini yaitu gelas kimia (Pyrex $\left.{ }^{\circledR}\right), \quad$ gelas Ukur $\left(\right.$ Pyrex $\left.^{\circledR}\right)$, kanula, kuvet, pipa kapiler, pipet tetes, spoit, seperangkat alat maserasi, seperangkat alat rotavapor, spektorofotometri $U v$-vis, seperangkat alat glukometer (Gluco $\mathrm{DR}^{\circledR}$ ), seperangkat alat sentrifugasi, tabung sentrifuge dan timbangan O'hauss $\left(\right.$ Camry $\left.^{\circledR}\right)$.

Bahan yang digunakan pada penelitian ini yaitu aquadest, aloksan, asam klorida, asam asetat glasial, daun sirsak (Annona muricata Linn), EDTA, etanol, ketamin, n-butanol, $\mathrm{NaCl}, \mathrm{Na}-\mathrm{CMC}, \mathrm{Na}_{2} \mathrm{SO}_{4}$, TBA (Asam tiobarbiturat) dan TCA (Asam trikloro asetat).

\section{Prosedur Kerja}

\section{Penyiapan alat dan bahan}

Alat dan bahan disiapkan sesuai dengan kebutuhan penelitian yang akan dilaksanakan.

\section{Pengambilan dan pengolahan sampel}

Sampel daun sirsak (Annona muricata Linn) diambil di kota Makassar. Sampel kemudian dibersihkan dari kotoran yang melekat 
Uji Aktivitas Antioksidan Ekstrak Etanol Daun Sirsak Pada Tikus Putih Diabetes Melitus Yang Diinduksi Aloksan Dengan Parameter Malondialdehid

dengan menggunakan air mengalir lalu dikeringkan dengan cara dianginanginkan. Setelah kering sampel dipotong-potong kecil, kemudian siap untuk diekstraksi dengan metode maserasi.

\section{Preparasi ekstrak daun sirsak}

Sampel berupa daun sirsak (Annona muricata Linn) sebanyak 200 gram dimasukkan ke dalam wadah maserasi, lalu ditambahkan pelarut etanol sebanyak $2000 \mathrm{ml}$ hingga simplisia tersebut terendam, dibiarkan selama 5 hari dalam bejana tertutup dan terlindung dari cahaya matahari langsung sambil diaduk secara periodik, setelah $5 \times 24$ jam dilakukan penyaringan dan ampasnya dimaserasi kembali dengan cairan penyari yang baru. Maserasi dilakukan sebanyak 2 kali dan diperoleh ekstrak etanol cair. Hasil penyarian yang diperoleh kemudian diuapkan dengan menggunakan rotavapor.

\section{Pembuatan Aloksan $110 \mathrm{mg} / \mathrm{kgBB}$}

Sebanyak 220mg aloksan ditambahkan larutan $\mathrm{NaCl} 25 \mathrm{ml}$, dihomogenkan kemudian dicukupkan volumenya hingga $50 \mathrm{~mL}$.

\section{Pembuatan larutan Na-CMC 1\%}

Sebanyak 1 gram $\mathrm{Na}-\mathrm{CMC}$ dimasukkan sedikit demi sedikit kedalam $50 \mathrm{ml}$ air suling panas sambil diaduk dengan menggunakan pengaduk elektrik hingga terbentuk larutan yang homogen, kemudian dicukupkan volumenya hingga $100 \mathrm{ml}$. Pembuatan EDTA 10\%

Sebanyak 10 gram EDTA ditimbang lalu dilarutkan dengan sedikit aquadest hingga homogen kemudian dicukupkan volumenya hingga $100 \mathrm{ml}$.

\section{Pembuatan Asam Asetat 10\%}

Sebanyak $10 \mathrm{ml}$ asam asetat dilarutkan dengan sedikit aquadest kemudian diencerkan sampai volume larutan menjadi $100 \mathrm{ml}$.

\section{Pembuatan TCA 10\%}

Sebanyak 10 gram asam
trikoloroasetat ditimbang lalu
dilarutkan dengan sedikit aquadest,
kemudian diencerkan sampai volume
larutan menjadi $100 \mathrm{ml}$.

\section{Pembuatan $\mathrm{Na}_{2} \mathrm{SO}_{4} 2 \mathrm{~mol} / \mathrm{L}$}

Sebanyak 14,204 gram natrium sulfat ditimbang lalu dilarutkan dengan sedikit aquadest, kemudian diencerkan sampai volume larutan menjadi $50 \mathrm{ml}$.

\section{Pembuatan TBA}

Sebanyak $100 \mathrm{mg}$ asam tiobarbiturat ditimbang lalu dilarutkan dengan sedikit aquadest, kemudian diencerkan sampai volume larutan menjadi $50 \mathrm{~mL} \mathrm{Na}_{2} \mathrm{SO}_{4}$.

\section{Pembuatan sediaan uji}

Ekstrak etanol daun sirsak (Annona muricata $\mathrm{L}$ ) dibuat sediaan uji 
Uji Aktivitas Antioksidan Ekstrak Etanol Daun Sirsak Pada Tikus Putih Diabetes Melitus Yang Diinduksi Aloksan Dengan Parameter Malondialdehid

dengan konsentrasi $2,5 \%$ dan $5 \%$.

Cara pembuatan sediaan uji adalah ekstrak etanol daun sirsak (Annona muricata L) ditimbang sebanyak 2,5 gram dan disuspensikan kedalam 100 $\mathrm{mL}$ Na.CMC. Dilakukan hal yang sama untuk pembuatan ekstrak etanol daun sirsak (Annona muricata L) $5 \%$ dengan menimbang ekstrak sebanyak 5 gram dan disuspensikan kedalam $100 \mathrm{~mL}$ Na.CMC.

\section{Perlakuan terhadap hewan uji}

Pada tahap ini akan diuji pengaruh konsentrasi ekstrak daun sirsak (Annona muricata Linn)pada hewan uji. Sebanyak 9 ekor tikus jantan umur 2-3 bulan dengan berat badan 100-200 gram, dibagi menjadi 3 kelompok perlakuan, tiap perlakuan terdiri dari 3 ekor tikus. Sebelum perlakuan, tikus diadaptasikan selama 1 minggu dengan pemberian komersial dan air minum secara ad libitium. Perlakuan dimulai dengan tikus dipuasakan selama 8 jam dan selanjutnya diukur kadar glukosa darah awal yang kemudian masingmasing tikus diinduksi aloksan dengan dosis $110 \mathrm{mg} / \mathrm{kg}$ BB secara intraperitoneal, dibiarkan selama 3 hari dan diukur kadar glukosa darah induksi dan diukur absorbannya sebagai nilai MDA awal, selanjutnya dilakukan perlakuan selama 12 hari adalah sebagai berikut:

1. Kelompok I (kontrol), yaitu tikusdiberikan Na-CMC 1\%

2. Kelompok II, yaitu tikus diberi ekstrak etanoldaun sirsak (Annona muricata Linn) konsentrasi 2,5\%

3. Kelompok III, yaitu tikus diberi ekstrak etanoldaun sirsak (Annona muricata Linn) konsentrasi $5 \%$

Selama penelitian, semua tikus diamati kadar gula darahnya setelah pemberian terapi ekstrak. Pada akhir penelitian, semua tikus diambil darah untuk pemeriksaan MDA.

\section{Pengambilan darah hewan uji}

Proses pengambilan darah pada hewan uji tikus (Rattus norvegicus) dilakukan secara plexus retroorbitalis. Tikus diinjeksi dengan ketamin $0,3 \mathrm{~mL}$ (Ketamin hidrocloride $50 \mathrm{mg} / \mathrm{mL}$ ) secara intraperitoneal. Kemudian pipa kapiler digoreskan pada medial canthus mata dibawah bola mata kearah foramen opticus. Pipa kapiler diputar sampai melukai plexus dan darah ditampung pada vial yang telah diberi EDTA.

\section{Analisis MDA}

Darah dikumpulkan dalam vial yang berisi larutan EDTA. Sebanyak $0,5 \mathrm{ml}$ darah dimasukkan kedalam tabung sentrifuge dan kemudian protein diendapkan dengan 
Uji Aktivitas Antioksidan Ekstrak Etanol Daun Sirsak Pada Tikus Putih Diabetes Melitus Yang Diinduksi Aloksan Dengan Parameter Malondialdehid

menambahkan $2,5 \mathrm{ml}$ dari $20 \mathrm{~g} / \mathrm{mL}$ asam trikloroasetat. Setelah itu disentrifuge pada $1000 \mathrm{rpm}$ selama 10 menit kemudian supernatant dipisahkan. Endapan protein disuspensikan kembali dalam 2,5 ml asam asetat dan ditambahkan $3 \mathrm{ml}$ asam tiobarbiturat $(2 \mathrm{~g} / \mathrm{L}$ dalam $2 \mathrm{~mol} / \mathrm{L}$ $\mathrm{Na}_{2} \mathrm{SO}_{4}$ ). Campuran reaksi dipanaskan dalam waterbath selama 30 menit,kemudian didinginkan cepat dalam ice bath untuk menghentikan reaksi, kemudian diekstraksi dengan menambahkan n-butanol sebanyak 4 $\mathrm{ml}$ dan disentrifuge kembali pada 3000 rpm selama 10 menit. Hasil sentrifuge tersebut diukur absorbansinya pada spektrofotometri dengan panjang gelombang $532 \mathrm{~nm}$ (Lefévre et al, 1996).

\section{Analisis Data}

Data penelitian yang diperoleh, dikumpulkan dan kemudian diolah dan di analisis secara statistik berdasarkan analisis RAK ( Rancangan Acak Kelompok ).

\section{HASIL PENELITIAN}

Tabel 1. Hasil perhitungankadar MDA induksi dan MDA terapi pada tikus (Rattus norvegicus) Diabetes mellitus

\begin{tabular}{l|l|l|l|l}
\hline \multirow{2}{*}{ Perlakuan } & \multirow{2}{*}{ Replikasi } & \multicolumn{3}{|l}{ Kadar Malondialdehid (ppm) } \\
\cline { 3 - 5 } & & Na.CMC & Ekstrak 2,5\% & Ekstrak 5\% \\
\hline \multirow{3}{*}{ Induksi } & I & 105,67 & 249 & 569 \\
\cline { 3 - 5 } & II & 42,3 & 195,67 & 759 \\
\cline { 3 - 5 } & III & 159 & 195,67 & 1219 \\
\hline Rata-rata & $\mathbf{1 0 2 , 3 2}$ & $\mathbf{2 1 3 , 4 6}$ & $\mathbf{8 4 9}$ \\
\hline \multirow{3}{*}{ Terapi } & I & 959 & 572,3 & 539 \\
\cline { 3 - 5 } & II & 1162,3 & 1029 & 659 \\
\cline { 2 - 5 } & III & 1002,3 & 1552,33 & $\mathbf{5 2 2 , 3}$ \\
\hline \multicolumn{2}{l|}{ Rata-rata } & $\mathbf{1 0 4 1 , 2}$ & $\mathbf{1 0 5 1 , 2 1}$ & $\mathbf{5 7 3 , 4 3}$ \\
\hline
\end{tabular}

\section{PEMBAHASAN}

Pengujian aktivitas antioksidan ekstrak etanol daun sirsak (Annona muricata $\mathrm{L})$ dengan parameter MDA dilakukan dengan metode Thiobarbiturat Acid (TBA) yang didasarkan pada pembentukan reaksi antara 1 molekul MDA dengan 2 molekul TBA (Thiobarbiturat Acid) yang menghasilkan warna merah yang dapat menyerap cahaya pada panjang gelombang $532 \mathrm{~nm}$. Semakin pekat warna yang dihasilkan maka konsentrasi MDA juga semakin tinggi (Arkhaesi, 2008).

Jumlah MDA yang terbentuk menggambarkan proses peroksidasi lipid. dimana makin tinggi absorbansi 
Uji Aktivitas Antioksidan Ekstrak Etanol Daun Sirsak Pada Tikus Putih Diabetes Melitus Yang Diinduksi Aloksan Dengan Parameter Malondialdehid

MDA semakin besar aktivitas radikal bebas, sebaliknya semakin rendah absorbansi MDA semakin kecil aktivitas radikal bebas. Metode ini merupakan metode yang paling banyak dan paling sering digunakan untuk mengukur keberadaan radikal bebas, mudah dikerjakan, mempunyai kepekaan yang cukup tinggi, mudah diaplikasikan untuk berbagai sampel.

Penelitian ini menggunakan tikus (Rattus norvegicus) dikarenakan genetik, karakteristik biologi dan perilakunya sangat mirip manusia dan banyak gejala kondisi manusia dapat direplikasi pada tikus. Tikus betina tidak digunakan dalam penelitian ini, karena sistem hormonalnya tidak stabil dibandingkan dengan tikus jantan sehingga dapat mempengaruhi hasil penelitian.

Sebelum perlakuan, tikus dipuasakan \pm 8 jam untuk meminimalkan faktor pengaruh makanan pada pengukuran kadar glukosa darah,kemudian diinduksi dengan aloksan $110 \mathrm{mg} / \mathrm{kgBB}$ secara intraperitonial. Aloksan digunakan sebagai penginduksi diabetes pada tikus, karena aloksan akan merusak sel-sel penghasil insulin yaitu sel $\beta$ pulau Langerhans dengan cara reduksi aloksan menjadi asam dialurat yang kemudian mengalami reoksidasi menjadi aloksan sehingga menghasilkan radikal ion superoksida yang kemudian terbentuk radikal bebas hidrogen peroksida yang dapat menyerang komponen penyusun sel sehingga menyebabkan kerusakan sel pada sel $\beta$ - pulau Langerhans yang menyebabkan pankreas tidak mampu menghasilkan insulin.

Grafik kadar MDA pada gambar 1 menunjukkan bahwa pada kelompok Na.CMC dan ekstrak etanol daun sirsak 2,5\% terjadi kenaikan kadar MDA induksi dan setelah terapi selama 12 hari, dimana kadar rata-rata MDA induksi untuk kelompok Na.CMC adalah 103,32 ppm dan untuk ekstrak 2,5\% adalah 213,46 ppm. Setelah terapi selama 12 hari, diperoleh data Kadar rata-rata MDA kelompok Na.CMC adalah 1041,2 ppm dan ekstrak 2,5\% adalah 1051,21 ppm.

Kelompok ekstrak etanol daun sirsak 5\% terjadi penurunan kadar MDA dimana kadar MDA rata-rata induksi yaitu 849 ppmdan kadar MDA rata-rata setelah terapiyaitu 573,4 ppm.

Data pengukuran kadar MDA yang diperoleh, kemudian dilakukan analisis statistik dengan metode Rancangan Acak kelompok (RAK) untuk mengetahui adanya pengaruh pemberian dari Na.CMC, Ekstrak 
Uji Aktivitas Antioksidan Ekstrak Etanol Daun Sirsak Pada Tikus Putih Diabetes Melitus

Yang Diinduksi Aloksan Dengan Parameter Malondialdehid

etanol daun sirsak 2,5\% dan 5\% dalam menurunkan kadar MDA.

Berdasarkantabel Anava dapat dilihat perbedaan yang nyata pada perlakuan awal ( setelah induksi ) dan akhir( setelah pemberian Na.CMC dan ekstrak etanol 2,5\% dan 5\%) dalam menurunkan MDA, dimana nilai $\mathrm{FH}$ $(18,094)>$ FT $5 \%(3,88)$ dan $>1 \%(6,93)$. Antar kelompok Na.CMC, ekstrak etanol daun sirsak $2,5 \%$ dan $5 \%$ tidak terdapat perbedaan yang nyata dimana nilai $\mathrm{FH}(0,471)<\mathrm{FT} 5 \%$ $(4,75)$ dan $1 \% \quad(9,33)$. Selanjutnya dilakukan uji Jarak Nyata Terdekat Duncan (JNTD) berdasarkan nilai koefisien keseragaman $(\mathrm{KK})>10 \%$ dimana nilai $\mathrm{KK}$ yang diperoleh yaitu sebesar 39,08\%.

Berdasarkan uji lanjutan JNTD, dapat dilihat pada tabel bahwa. setelah terapi selama 12 harimemperlihatkan adanya perbedaan yang nyata antara kelompok Ekstrak 5\% dengan ekstrak $2,5 \%$ dan kelompok ekstrak 5\% dengan Kelompok Na.CMC, sedangkan pada kelompok Ekstrak 2,5\% dengan kelompok Na.cmc tidak memperlihatkan adanya perbedaan yang nyata dalam menurunkan kadar MDA darah tikus.

Kelompok Na.CMC terjadi kenaikan MDA dimana hal ini dikarenakan Na.CMC tidak mengandung komponen antioksidan yang dapat menurunkan kadar MDA dan Na.CMC tidak memiliki efek terhadap tikus sehingga tikus pada kelompok ini terus menerus terpapar oleh radikal bebas yang menyebabkan terjadinya peningkatan MDA.

Penurunan kadar MDA pada kelompok ekstrak etanol daun sirsak (Annona muricata L) $5 \%$ menunjukkan bahwa adanya penghambatan pada proses peroksidasi lipid sehingga MDA yang terbentuk berkurang. Efek penurunan ini diasumsikan karena senyawa aktif yang terkandung pada daun sirsak memiliki efek antioksidan. Hasil skrining fitokimia diperoleh bahwa ekstrak etanol daun sirsak mengandung senyawa alkaloid, flavonoida, glikosida, saponin, tanin, steroida (Rianes, 2012). Menurut Hans \& Heldt (2005)selain flavonoid, golongan tanin dan alkaloid juga mempunyai aktivitas antioksidan. Pada ekstrak etanol daun sirsak 2,5\% terjadi kenaikan kadar MDA dikarenakan rendahnya konsentrasi yang digunakan sehingga belum mampu untuk menurunkan kadar MDA namun ekstrak 2,5\% ini dapat menurunkan kadar glukosa darah pada tikus.

Berdasarkan hal tersebut, dapat disimpulkan bahwa ekstrak etanol 
Uji Aktivitas Antioksidan Ekstrak Etanol Daun Sirsak Pada Tikus Putih Diabetes Melitus Yang Diinduksi Aloksan Dengan Parameter Malondialdehid

daun sirsak $5 \%$ berpotensi sebagai

antioksidan yang dapat menurunkan kadar MDA tikus (Rattus norvegicus) diabetes yang diinduksi aloksan.

\section{KESIMPULAN DAN SARAN}

Berdasarkan penelitian yang dilakukan dapat disimpulkan bahwa ekstrak etanol daun sirsak (Annona muricata L) $5 \%$ dapat menurunkan kadar MDA tikus (Rattus norvegicus) diabetes melitus yang diinduksi aloksan sedangkan pada ekstrak etanol daun sirsak $2,5 \%$ belum dapat menurunkan kadar MDA.

\section{DAFTAR PUSTAKA}

Adiyati, A. H. 2011.Aktivitas Antidiabetes Fraksi N-Heksana, Etil Asetat Dan Air Ekstrak Etanol Daun Sirsak (Annona Muricata L.) Pada Tikus Putih Jantan Diabetes Aloksan. (Skripsi) Bandung : Universitas Padjajaran

Bassett, J. 1994. Buku Ajar Vogel : Kimia Analisis Kuantitatif Anorganik. Penerbit Buku Kedokteran (EGC). Jakarta.

Dipiro, et al. 2008. Pharmacotherapy A Pathophysiologic Approach 7th.United States : Mc Graw Hill Medical.

Direktorat Jenderal Pengawasan Obat dan Makanan. 1986. Sediaan Galenik. Jakarta : Departemen Kesehatan RI.

Goodman \& Gilman. 2006. The Pharmacological Basic of Therapeutics 1st edition. New York : Mc Graw Hill.
Hans, Heldt W. \& Plant Biochemistry Thirc _...ion. San Diego : Elsevier Academic Press

Hariana, A. 2007. Tumbuhan Obat dan Khasiatnya Seri 3. Jakarta : Penebar Swadaya

Hartini, S. 2009. Diabetes ? Siapa Takut !!!. Bandung : Mizan Media Utama (MUU).

Jassin, \& Soemkari.1992. Zoologi Vertebrata untuk Perguruan Tinggi. Surabaya : PT. Antariksa.

Khalida, R. 2010. Analisis Tingkat Peroksida Lipid dengan MDA (Online),(http://ammikhalid89.w ordpress.com/2010/10/22/analis is-tingkat-peroksidasi-lipiddengan-mda/ diakses 16 Februari 2013).

Khopkar, S.M. 2008. Konsep Dasar Kimia Analitik. Jakarta : UIPress.

Levéfre et al. 1996. Determination of plasma protein-bound Malondialdehyde by Derivative Spectrophotometry. Eur J Clin Chem Clin Biochem $34: 631$ 636

Mc Kee, T., Mc Kee, J.R. 2003. Aerobic metabolism II: electron transport and oxidative phosphorylation In: Biochemistry the molecular basis of life. 3rd ed. McGrawHill, NY 10020. 319-326.

Malole, M.B.M, dan Pramono, C.S.I.1989. Penggunaan Hewan-Hewan Percobaan di Laboratorium. Departemen Pendidikan dan Kebudayaan, Direktorat. 
Matsumono $\mathrm{K}$ et al. 2002. A novel method for the assay of $\alpha$ glucosidase inhibitory activity using a multi-channel oxygen sensor. J Anal Sci 18: 13151319.

Murray KR. 2003. Harper's Illustrated Biochemistry. Ed ke-26. London: Longe Medical Pub.

Mycek, M.J.Harvey, R.A.\&Champe, P.C 2001.Farmakologi Ulasan Bergambar Edisi II. Jakarta : Widya Medika

National Tropical Botanical Garden. 2011. (Online) (http://www.ntbg.org/plants/plan t details.php?plantid $=10272$ Diakses 16 Februari 2013).

Nugroho, A. E. 2006. Hewan Percobaan Diabetes Melitus: Patologi dan Mekanisme Aksi Diabetogenik. Bioverditas Vol 7, No $4: 378-382$.

NWLSS ${ }^{\text {TM }}$. 2011. Malondialdehyde Assay(Online),(https://www.funa koshi.co.jp/data/datasheet/NWS INWK-MDA01.pdf diakses 28 Maret 2013)

Raintree Nutritionlnc. 2004.Graviola Monograph(Online),(http://www. raintree.com/GraviolaMonograp h.pdf diakses 28 Maret 2013)

Rianes, R. 2012. Karakteristik Simplisia dan Skrining Fitokimia serta Uji Aktivitas Antioksidan Jus Buah Sirsak dan Ekstrak Etanol Daun Sirsak (Annona muricata L) (Skripsi). Medan : Universitas Sumatera Utara.
Silalahi, J. 2006. Makanan Fungsional. Yogyakarta : Kanisius.

Siswanto, W. P . 2012. Pemberian Suspensi Bubuk Kedelai Dapat Menurunkan Kadar Malondialdehid (MDA) Serum pada Tikus Putih Diabetes Melitus yang Diinduksi Streptozotocin.Gaster Vol. 9 5561.

Sudjadi. 2010. Kimia Analisis Farmasi. Yogyakarta : Pustaka Pelajar.

Van Steenis, C.G., 1975, Flora Voor de Scholen in Indonesie, diterjemahkan oleh Sorjowinoto, M., edisi VI, Jakarta : PT. Pradnya Paramitha.

Winarsi, H. 2007. Antioksidan Alami dan Radikal bebas. Kanisius, Yogyakarta.

Wiyono,P. 2003. Peranan Hiperglikemia Terhadap Terjadinya Komplikasi Kronik Diabetes Melitus. Berkala IImu Kedokteran, 35, 1.

Widowati W. 2008. Potensi antioksidan sebagai antidiabetes. JKM 7 : 193-202.

Yoshikawa, Toshikazu, \& Naito Y. 2002. What is Oxidative Stress ? Journal of Japan Medical Association,Vol. 124, No. 11, 1549-1553. 